\title{
The Ultrasonographic Evaluation of Vena Cava Inferior Diameter as an Intraabdominal Pressure Indicator
}

\author{
İntraabdominal Basınç Göstergesi Olarak Vena Kava İnferior Çapının Ultrasonografi ile \\ Değerlendirilmesi
}

\author{
İzzettin ERTAŞ ${ }^{1}$ \\ (D) 0000-0001-7364-6564 \\ Mehmet Zeki BULDANLI ${ }^{2}$ \\ (D) 0000-0002-6491-7630 \\ Abdullah Sadık GİRIŞGín ${ }^{3}$ \\ (D) 0000-0003-2669-0532 \\ İbrahim Ali ÖZEMİR ${ }^{4}$ \\ (D) 0000-0001-8693-9358 \\ Nuray ÇOLAPKULU ${ }^{4}$ \\ (1) 0000-0002-3033-8702
}

\begin{abstract}
Aim: Intraabdominal hypertension (IAH) and abdominal compartment syndrome (ACS) are accepted as a significant cause of morbidity and mortality. The aim of this study is to investigate the utility of ultrasonography (US) as a non-invasive technique for evaluation of IAH, ACS and abdominal perfusion pressure (APP).

Material and Methods: Ninety-five patients with intensive care unit requirement, who applied to emergency department and also received a urine catheter were included in the study. During first evaluation intraabdominal pressure (IAP) calculated via measuring intravesical pressure. Inferior vena cava (VCI) diameter, pulsed wave (PW) and central venous pressure (CVP) were recorded by using US. Patients were divided into three groups according to their IAP (IAP $<12 \mathrm{~mm} \mathrm{Hg}$, IAP $=12-20 \mathrm{~mm} \mathrm{Hg}$, IAP $>20 \mathrm{~mm} \mathrm{Hg}$ ). Each group were evaluated separately in terms of VCI inspirium (i) and expirium (e) diameters.

Results: Mean age of the patients was $68.6 \pm 14.5$ (range, 24-91) years. Median IAP was 9.55 $\mathrm{mm} \mathrm{Hg}$ and mean APP was $70.41 \pm 17.67 \mathrm{~mm} \mathrm{Hg}$. VCli and VCIe diameters were significantly different in Group 1 with normal $(<12 \mathrm{~mm} \mathrm{Hg}$ ) IAP $(\mathrm{p}<0.001)$. Correlation between VCI diameter and CVP among all patients were significant $(\mathrm{p}<0.001)$.

Conclusion: A significant correlation between both VCIi and VCIe diameters, and CVP values in case of IAH presence was found in this study. We think that, recognition of IAP with noninvasive methods via evaluating high values of VCI diameter and CVP is effective for reducing morbidity and mortality providing early diagnosis and treatment.
\end{abstract}

${ }^{1}$ Dr. Nafiz Körez Sincan State Hospital Department of Emergency Medicine, Ankara, Turkey

${ }^{2}$ University of Health Sciences Gülhane Training and Research Hospital Department of General Surgery, Ankara, Turkey

${ }^{3}$ Necmettin Erbakan University Meram Medical Faculty Department of Emergency Medicine, Konya, Turkey ${ }^{4}$ Istanbul Medeniyet University Göztepe Training and Research Hospital Department of General Surgery, Istanbul, Turkey

\section{Corresponding Author Sorumlu Yazar}

Mehmet Zeki BULDANLI

buldanli87@hotmail.com

Received / Geliş Tarihi : 15.06 .2020 Accepted / Kabul Tarihi : 07.10.2020 Available Online /

Çevrimiçi Yayın Tarihi : 25.12.2020
Keywords: Vena cava inferior; intraabdominal pressure; abdominal compartment syndrome; intraabdominal hypertension.

ÖZ

Amaç: İntraabdominal hipertansiyon (IAH) ve abdominal kompartıman sendromu (ACS) anlamlı morbidite ve mortalite nedenleri arasında kabul edilmektedir. Bu çalışmanın amacı olarak ultrasonografi (US) ile yapılabilirliğinin araştırılmasıdır.

Gereç ve Yöntemler: Çalışmaya acil servise başvuran ve yoğun bakım ihtiyacı olan mesane sondası takılan 95 hasta dahil edildi. İlk muayenede mesane içi basınç ölçümü yöntemi ile intraabdominal basınçları (IAP) ölçüldü. Vena kava inferior (VCI) çapı, pulsed wave (PW) ve santral venöz basınç (CVP) değerleri US ile kaydedildi. Hastalar IAP değerlerine göre 3 gruba (İAB $<12 \mathrm{~mm} \mathrm{Hg}$, İAB =12-20 mm Hg, İAB > $20 \mathrm{~mm} \mathrm{Hg}$ ) ayrıldı. Her grup kendi içinde VCI inspiryum (i) çapı ve VCI ekspiryum (e) çapı ile ayrı ayrı değerlendirildi.

Bulgular: Hastaların yaş ortalaması $68,6 \pm 14,5$ (aralık, 24-91) yıl idi. Hastaların ortanca IAP

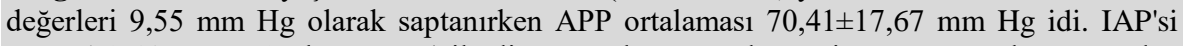
normal $(<12 \mathrm{~mm} \mathrm{Hg})$ olan Grup 1 ile diğer gruplar arasında VCIi ve VCIe çapları açısından istatistiksel anlamlı fark saptandı $(\mathrm{p}<0,001)$. Tüm hastalarda, VCI çapı ile CVP arasındaki korelasyon anlamlı bulundu $(\mathrm{p}<0,001)$.

Sonuç: Bu çalışmada, IAP varlığı ile hem VCIi ve VCIe çapları arasında, hem de CVP değerleri arasında anlamlı bir korelasyon saptanmıştır. Yüksek VCI çap ve CVP değerlerinin değerlendirilerek IAP'ın non-invaziv yöntemlerle tanınmasının erken tanı ve tedavi imkanı sağlayarak morbidite ve mortaliteyi azaltmada etkili olabileceğini düşünmekteyiz.

Anahtar kelimeler: Vena kava inferior; intraabdominal basınç; abdominal kompartıman sendromu; intraabdominal hipertansiyon. IAH, ACS ve abdominal perfüzyon basıncı (APP) değerlendirilmesinin non-invaziv bir teknik 


\section{INTRODUCTION}

Intraabdominal hypertension (IAH) and abdominal compartment syndrome (ACS) are accepted as a significant cause of morbidity and mortality in both surgical and non-surgical patients. Increased intraabdominal pressure (IAP) can lead multiorgan dysfunction. Consequently in high risk patients, adding IAP measurement to other vital parameters has a significant prognostic value (1). Multiorgan dysfunction can be a preventable entity, if IAH and ACS are recognized in the early time period of treatment (1). Thus, decreasing IAP whether pharmacologically or surgically for maintaining peripheral organ perfusion becomes a requirement (2). Including $\mathrm{IAH}$, early diagnosis and intervention reduces morbidity and mortality in surgical patients (2-4). When urinary catheterization is the preferred invasive method for measuring IAP, in this study we aimed to reveal the utilization of ultrasonography (US) as a non-invasive technique for evaluating IAP, IAH and abdominal perfusion pressure (APP).

\section{MATERIAL AND METHODS}

Patients with urinary catheterization and intensive care unit (ICU) need that checked into emergency department between October 2012 and October 2013 were included in the study. Exclusion criteria were as followed; pregnancy, present nephrostomy, bladder surgery history, right ventricle deficiency, right ventricle hypertrophy, tricuspid valve dysfunction and pericardial tamponade. Same medical professionals measured blood pressure by using a sphygmomanometer, arterial pulse and central venous pressure (CVP). Ninety-five patients with surgical, nonsurgical and/or traumatic etiologies were included. IAP values were recorded for the first evaluation in emergency room or ICU. Vena cava inferior (VCI) diameters were measured with US. Demographic features of the patients, their mechanic ventilator requirements and first laboratory findings were recorded. IAP values were taken daily and simultaneous VCI diameters were measured during inspirium and expirium (VCIi, VCIe). US evaluation was made in supine position while convex probe was in epigastric region aiming for right shoulder. VCI diameter were measured at the site of right before it enters right atrium. Philips M2540A EnVisor C model C US was used. Highest and lowest pulsed wave (PW) Doppler values were recorded. Bladder pressure was measured for IAP. After inserting urinary catheter, $25 \mathrm{~mL}$ serum were injected into bladder and a CVP manometer was connected to the catheter. In supine position during expirium IAP was measured accepting the symphysis pubis as zero-reference point. Patients were divided into 3 groups according to IAP values in line with diagnostic options and general acceptance (5). Group 1; IAP <12 mm Hg, Group 2; IAP $=12-20 \mathrm{~mm} \mathrm{Hg}$, Group 3; IAP >20 mm Hg. Ethics committee approval was received for this study from Ethical Comittee of Necmettin Erbakan University Meram Medical Faculty. The registration identification number is $2012 / 60$. All included patients and/or their relatives signed an informed consent form.

\section{Statistical Analysis}

Descriptive statistics were presented as frequency and percentages for categorical variables. Distribution of the numerical data were examined by Kolmogorov-Simirnov test. Mean and standard deviation were given for variables distributed normally, while median, $1^{\text {st }}$ and $3^{\text {rd }}$ quartile and minimum-maximum values were given for variables not distributed normally. Normally distributed variables were compared between groups by ANOVA and post hoc analysis was done with Tukey method. Kruskal-Wallis test was used for comparison of groups in terms of variables not distributed normally, and post hoc analyses were performed with the Mann Whitney U test with Bonferroni correction. Spearman correlation coefficient was used for the correlation analysis. SPSS v.16 was used for statistical analyses, and a v value of 0.05 was accepted as significant.

\section{RESULTS}

During the 12 months of study period, a total of 95 patients that were admitted to emergency department were included in the study. There were 54 (56.8\%) males and $41(43.2 \%)$ females, with a mean age of $68.6 \pm 14.5$ (range, 24-91) years. Mean systolic and diastolic pressure were $111.7 \pm 22.5$ (range, 50-176) $\mathrm{mm} \mathrm{Hg}$ and $65.6 \pm 16.1$ (range, 40-140) $\mathrm{mm} \mathrm{Hg}$ respectively.

Fifty-eight $(61.1 \%)$ patients had abdominal distention, $14(14.7 \%)$ patients had abdominal defense and rebound findings on physical examination. Seventeen (17.9\%) patients had abdominal defense without rebound. Of these 58 patients with abdominal distention, IAH was identified in $29(50.0 \%)$ patients. Five $(5.3 \%)$ patients had IAH without abdominal distention. Distribution of patients' complaints and symptoms are revealed in Table 1 .

In Table 2, IAP, mean arterial pressures (MAP), PW, CVP, APP, VCIi and VCIe values are shown.

Table 1. Distribution of complaints and symptoms during first emergency department evaluation, n (\%)

\begin{tabular}{lc}
\hline Deterioration of general condition & $48(50.5)$ \\
Abdominal pain & $16(16.8)$ \\
Shortness of breath & $15(15.8)$ \\
Gastrointestinal bleeding & $5(5.3)$ \\
Syncope & $4(4.2)$ \\
Fever & $3(3.2)$ \\
Low urinary output & $2(2.1)$ \\
Toxic exposure & $2(2.1)$ \\
\hline
\end{tabular}

Table 2. IAP, MAP, PW, CVP, APP, VCIi and VCIe values of the patients

\begin{tabular}{|c|c|c|c|}
\hline & Median & $\mathbf{Q}_{1}-\mathbf{Q}_{3}$ & Min-Max \\
\hline IAP $(\mathrm{mm} \mathrm{Hg})$ & 9.55 & $5.1-13.9$ & $2.2-35.2$ \\
\hline MAP $(\mathrm{mm} \mathrm{Hg})$ & 80 & $70-90$ & $43.3-150$ \\
\hline PW (highest) & 45 & $37-48$ & $25-80$ \\
\hline PW (lowest) & 29 & $25-35$ & $11-48$ \\
\hline \multirow[t]{2}{*}{$\mathbf{C V P}(\mathrm{cm})$} & 9 & $7-11$ & $0-28$ \\
\hline & \multicolumn{2}{|c|}{ Mean \pm SD } & Min-Max \\
\hline $\mathbf{A P P} *(\mathrm{~mm} \mathrm{Hg})$ & \multicolumn{2}{|c|}{$70.41 \pm 17.67$} & $18.0-141.9$ \\
\hline VCIi* (mm) & \multicolumn{2}{|c|}{$1.74 \pm 0.44$} & $0.90-3.00$ \\
\hline VCIe* $(\mathrm{mm})$ & \multicolumn{2}{|c|}{$1.89 \pm 0.46$} & $0.98-3.14$ \\
\hline
\end{tabular}

IAP: Intraabdominal pressure, MAP: Mean arterial pressure, PW: Pulsed wave, CVP: Central venous pressure, APP: Abdominal perfusion pressure, VCIi: Vena cava inferior during inspirium, VCIe: Vena cava inferior during expirium, $\mathrm{Q}_{1}: 1^{\text {st }}$ quartile, $\mathrm{Q}_{3}: 3^{\text {rd }}$ quartile, Min: Minimum, Max: Maximum, SD: Standard deviation 
Mean VCIi diameter and mean VCIe were $1.74 \pm 0.44$ (range, 0.90-3.00) $\mathrm{mm}$ and 1.89 \pm 0.46 (range, 0.98-3.14) $\mathrm{mm}$, respectively. Median highest $\mathrm{PW}$ value was 45 (range, 25-80) $\mathrm{cm} / \mathrm{sec}$ and median lowest PW value was 29 (range, $11-48$ ) $\mathrm{cm} / \mathrm{sec}$. Median CVP value was 9 (range, $0-28) \mathrm{cm} \mathrm{H}_{2} \mathrm{O}$. There is a positive correlation between CVP and VCIi ( $\mathrm{r}=0.499, \mathrm{p}<0.001)$, and CVP and VCIe $(\mathrm{r}=0.444, \mathrm{p}<0.001)$ values. Correlation between IAP and VCIi $(r=0.596, p<0.001)$, and VCIe $(r=0.581, p<0.001)$ diameters were found significant. IAP and PW (both high and low) values did not correlate statistically ( $\mathrm{p}=0.318$ and $\mathrm{p}=0.669$, respectively).

APP (mean arterial pressure-intraabdominal pressure) upper limit is accepted as $60 \mathrm{~mm} \mathrm{Hg}$. In our study $30 \%$ of patients had less than $60 \mathrm{~mm} \mathrm{Hg}$ of APP value.

There were $59(62.1 \%), 25(26.3 \%)$ and $11(11.6 \%)$ patients in Group 1, Group 2, and Group 3 respectively (Table 3). Among all groups there were a significant difference between mean values of VCIi and VCIe $(\mathrm{p}<0.001)$. Patients in Group 1 with normal $(<12 \mathrm{~mm} \mathrm{Hg})$ IAP values had statistically different VCIi and VCIe diameters when compared to other groups $(\mathrm{p}<0.001)$.

CVP values differ between all groups $(p=0.003)$. When CVP values were compared, there was significant difference between Group 1 and Group $3(\mathrm{p}=0.006)$, but no significance was found between Group 1 and Group 2 $(\mathrm{p}=0.093)$, and Group 2 and Group $3(\mathrm{p}=0.496)$.

\section{DISCUSSION}

Intraabdominal hypertension is a sustained or repeated IAP more than $12 \mathrm{~mm} \mathrm{Hg}$. Increased IAH may lead splanchnic hypoperfusion and/or multiorgan dysfunction if left untreated. After abdominal surgery IAP varies approximately from 3 to $15 \mathrm{~mm} \mathrm{Hg}$. IAH can occur during endotracheal entubation for short term. Also patients with burns, pancreatitis, traumatic injury or shock status may develop IAH. Excessive intravenous fluid administration can cause IAH. Prevalence of IAH in ICU patients is 18$58.8 \%$ (6). In our study we calculated the incidence of IAH as $37.9 \%$. Another study conducted by Malbrain et al. (7) revealed that the incidence is $59 \%$ in critically ill patients. In ICU patients, evaluating IAH should be considered because of its high incidence rates. Simonson et al. (8) reported that higher survival rates may be possible with early interventions via education of health professionals in related departments about measuring and evaluation of IAP. Arabadzhiev et al. (9) reported in their study with ICU patients that early decompression decreases mortality rates. Therefore, routine IAP evaluation in ICU population can reduce both mortality rates and length of hospital stay. Ravishankar et al. (10) reported that physicians usually evaluate IAH of their patients only if necessary under certain clinical conditions and in this study, only $27 \%$ of clinicians took measurement of IAH 4 to 8 hours intervals. Although it is the most accurate method to measure IAH directly with a catheter placed inside the abdomen, it is not practicable to be an invasive method and because of the risk of infection. Indirect measurements can be accomplished by other several methods (11). The most commonly used method of indirect measurement is the transvesical measurement method described by Kron et al (12). This method is an impractical method because it requires an invasive procedure such as bladder catheterization. The World Society of the Abdominal Compartment Syndrome (WSACS), an international multidisciplinary consensus to study the causes and consequences of abdominal hypertension, has not yet found a consensus on the amount of fluid to be delivered to the bladder in its studies (13). In addition, various manometers have been developed for continuous measurement and monitoring, but have not found sufficient use. Urinary infection which may occur in intensive care patients with infection tendency with a minor intervention may adversely affect the prognosis of these patients. Another indirect method of measurement was the measurement of catheter insertion into the VCI and was not favored by the presence of continuous catheter in the groin and complications related to catheter. Transgastric measurement method is difficult to use in practice due to the insertion of an intragastric balloon. Especially in ICU patients, continuous monitoring is not preferred because of complications caused by reflux and aspiration. In our study, technical difficulties can be eliminated by indirect measurement of IAP with US, and the presence of IAH can be determined with a standard approach.

In our study, IAP measurement was performed with the help of a manometer after giving $25 \mathrm{ml}$ of saline into the bladder via bladder catheter. The measurement of VCIi and VCIe diameters of the patients was non-invasive and provided faster results. A significant relationship was found between the patients' IAP and VCIi and VCIe diameters. In Group 1, an increase in the VCI diameter was observed in parallel with the increase in IAP; however, this increase did not change as the IAP stages increased and no difference was found. The reason for this is that the increase in advanced intraabdominal pressure has not been able to extend VCI more further. IAH benefits from medical treatment and early decompression surgeries when early recognition. Therefore, it is thought that the VCI measurements to be applied in patients will be useful in the diagnosis of IAP and increase in early period and this will give the chance of an early intervention in patients with IAP.

Table 3. Comparison of VCIi, VCIe and CVP values

\begin{tabular}{|c|c|c|c|c|}
\hline & $\begin{array}{c}\text { Group } 1(\mathrm{n}=59) \\
(\text { IAP }<12 \mathrm{~mm} \mathrm{Hg})\end{array}$ & $\begin{array}{c}\text { Group } 2(\mathrm{n}=25) \\
(\mathrm{IAP}=\mathbf{1 2 - 2 0} \mathrm{mm} \mathrm{Hg})\end{array}$ & $\begin{array}{c}\text { Group } 3(\mathrm{n}=11) \\
(\text { IAP }>20 \mathrm{~mm} \mathrm{Hg})\end{array}$ & $\mathbf{p}$ \\
\hline VCIi (mm) & $1.58 \pm 0.40$ & $1.90 \pm 0.39$ & $2.19 \pm 0.33$ & $<0.001$ \\
\hline VCIe (mm) & $1.75 \pm 0.44$ & $2.02 \pm 0.39$ & $2.35 \pm 0.36$ & $<0.001$ \\
\hline $\mathbf{C V P}(\mathrm{cm})$ & $8(5)[0-20]$ & $10(3)[4-22]$ & $12(4)[9-28]$ & 0.003 \\
\hline
\end{tabular}

were given as mean \pm standard deviation or median (interquartile range) [minimum-maximum] 
When an acute or chronic increase in IAP occurs, the diaphragm becomes elevated, leading to a progressive reduction in lung and chest wall compliance by increasing intrathoracic and pleural pressures. As a result, increased ventilation/perfusion mismatch leads to hypoxia, hypercapnia and mechanical ventilator requirement (14). The VCI diameter can alter by changes in respiration movements and total body fluid. During inspiration, intrapleural pressure becomes negative and causes increased venous return to the right side of the heart, leading to a reduction in intraluminal pressure. VCI was first shown as enlarged by Weil in patients with right heart failure. To date, VCI has been visualized to assess volume status in patients with heart failure and dialysis requirement (15). In a study conducted by Tetsuka et al. (16), it has been reported that VCIe is a marker of circulating blood volume. In particular, the correlation between VCI end-expiratory diameter and circulating blood volume is noteworthy. In our study, we found a significant relationship between VCIi and VCIe diameter and CVP.

Lyon et al. (15) demonstrated that the collapse of VCI diameter correlates with CVP in the supine position of a lying patient. Marcelino et al. (17) investigated whether the VCI was correlated with CVP in patients who were followed up in surgical or non-surgical ICUs and ultimately found that the VCI index (VCIe-VCIi / VCIe) correlated with CVP.

Wachsberg et al. (18) reported in their study of seven patients with IAH, intrahepatic VCI diameter was examined with computed tomography (CT) and US and the diameter of intrahepatic VCI was found increased in these patients. In our study, both inspiratory and expiratory diameters were measured where extrahepatic VCI enters to the right atrium of the heart. Also, CVP values of patients were measured and a significant correlation was found between CVP values and VCI diameters for each group. These results show us that both CVI diameter and CVP value are related and possible abnormal CVP increment may be warning for IAP elevation.

\section{CONCLUSION}

The significance of the correlation between the early stages of the elevated IAP and the increase in VCI diameters will allow early diagnosis and treatment of IAH. It should be kept in mind that high CVP measurements, like VCI diameter measurement, are also a warning to demonstrate IAP increase. Especially in the follow-up of ICU patients, the fact that IAP measurements should not be neglected, because IAP increase can be detected noninvasively in the early period. Thus, it can be concluded that the decrease in morbidity and mortality resulting from IAH can be achieved.

Ethics Committee Approval: The study was approved by the Ethics Committee of Necmettin Erbakan University Meram Faculty of Medicine (27.11.2012, 2012/60).

Conflict of Interest: None declared by the authors.

Financial Disclosure: None declared by the authors.

Acknowledgements: None declared by the authors.

\section{REFERENCES}

1. Rogers WK, Garcia L. Intraabdominal hypertension, abdominal compartment syndrome, and the open abdomen. Chest. 2018;153(1):238-50.

2. Cheatham ML. Nonoperative management of intraabdominal hypertension and abdominal compartment syndrome. World J Surg. 2009;33(6):1116-22.

3. Cheatham ML, Safcsak K. Is the evolving management of intra-abdominal hypertension and abdominal compartment syndrome improving survival? Crit Care Med. 2010;38(2):402-7.

4. Sarı R, Yabanoğlu H, Kuş M, Arer İM. Management and clinical outcomes of iatrogenic injury secondary to endoscopic retrograde cholangiopancreatography. Istanbul Med J. 2020;21(1):28-32.

5. Kirkpatrick AW, Roberts DJ, De Waele J, Jaeschke R, Malbrain MLNG, De Keulenaer B, et al. Intraabdominal hypertension and the abdominal compartment syndrome: updated consensus definitions and clinical practice guidelines from the World Society of the Abdominal Compartment Syndrome. Intensive Care Med. 2013;39(7):1190-206.

6. Quintel M, Pelosi P, Caironi P, Meinhardt JP, Luecke $\mathrm{T}$, Herrmann $\mathrm{P}$, et al. An increase of abdominal pressure increases pulmonary oedema in oleic acid induced lung injury. Am J Respir Crit Care Med. 2004;169(4):534-41.

7. Malbrain MLNG, Chiumello D, Pelosi P, Bihari D, Innes R, Ranieri VM, et al. Incidence and prognosis of intraabdominal hypertension in a mixed population of critically ill patients: a multiple-center epidemiological study. Crit Care Med. 2005;33(2):315-22.

8. Simonson JS, Schiller NB. Sonospirometry: a new method for noninvasive estimation of mean right atrial pressure based on two-dimensional echographic measurements of the inferior vena cava during measured inspiration. J Am Coll Cardiol. 1988;11(3):557-64.

9. Arabadzhiev GM, Tzaneva VG, Peeva KG. Intraabdominal hypertension in the ICU - a prospective epidemiological study. Clujul Med. 2015;88(2):188-95.

10. Ravishankar N, Hunter J. Measurement of intraabdominal pressure in intensive care units in the United Kingdom: a national postal questionnaire study. Br J Anaesth. 2005;94(6):763-6.

11. Lashutka MK, Chandra A, Murray HN, Phillips GS, Hiestand BC. The relationship of intraocular pressure to intracranial pressure. Ann Emerg Med. 2004;43(5):585-91.

12. Kron IL, Harman PK, Nolan SP. The measurement of intra-abdominal pressure as a criterion for abdominal re-exploration. Ann Surg. 1984;199(1):28-30.

13. Malbrain MLNG, Cheatham ML, Kirkpatrick A, Sugrue M, Parr M, De Waele J, et al. Results from the International Conference of Experts on Intraabdominal Hypertension and Abdominal Compartment Syndrome. I. Definitions. Intensive Care Med. 2006;32(11):1722-32.

14. Regli A, Pelosi P, Malbrain MLNG. Ventilation in patients with intra-abdominal hypertension: what every critical care physician needs to know. Ann Intensive Care. 2019;9(1):52. 
15. Lyon M, Blaivas M, Brannam L. Sonographic measurement of the inferior vena cava as a marker of blood loss. Am J Emerg Med. 2005;23(1):45-50.

16. Tetsuka T, Ando Y, Ono S, Asano Y. Change in inferior vena caval diameter detected by ultrasonography during and after hemodialysis. ASAIO J. 1995;41(1):105-10.

17. Marcelino P, Borba A, Fernandes AP, Marum S, Germano N, Lopes MRG. Non invasive evaluation of central venous pressure using echocardiography in the intensive care--specific features of patients with right ventricular enlargement and chronic exacerbated pulmonary disease. Rev Port Pneumol. 2006;12(6):637-58.

18. Wachsberg RH. Narrowing of the upper abdominal inferior vena cava in patients with elevated intraabdominal pressure: sonographic observations. J Ultrasound Med. 2000;19(3):217-22. 